\title{
Why Did Jesus Surrender to the Cross?
}

\section{The Historical Evidence}

\author{
John Mowbray \\ Independent scholar, London, United Kingdom \\ pugshole@btinternet.com
}

\begin{abstract}
Evidence from secular sources shows that the Romans did not attempt to crucify all in the empire who rose against them; rather, they crucified leaders as a warning to others, but often let followers go. Jesus believed or hoped that if he surrendered to the cross, though the Romans would crucify him as leader, they would let his followers go. He surrendered himself accordingly, to save his followers from suffering a similar fate. As a historical fact, this was successful, and his followers were preserved to become the beginnings of the church.
\end{abstract}

\section{Keywords}

historical Jesus - Roman criminal practice - surrender to the cross - forgiveness of sins - Mark 1.14-15

\section{The Search and Two Obvious Points}

This article makes a new search for historical evidence ${ }^{1}$ about Jesus' object in surrendering to the cross. It then follows where this evidence leads, setting to one side for the moment the traditional explanations for his surrender.

1 Agreeing with Rafael Rodriguez; that the texts that will be relied on are not 'history', but only sources of historical information, or (as I prefer to say) evidence of what happened, see Rodriguez's 'What is History? Reading John 1 as Historical Representation', JSHJ 16 (2018), pp. $3^{1-51}(34)$. 
Before this, though, two obvious points may be noted. One is that Jesus seems very unlikely to have gone to the cross for his own benefit; he could not take any personal benefit from doing so, but only suffering and death. It seems obvious, then, that he must have gone to the cross for the benefit of others. Secondly, while it is not easy at this stage to identify all those whom Jesus may have intended to benefit, his disciples and other friends and followers are obviously the most likely to have been included.

As to what benefit he intended to confer on them, we have two further relevant historical facts: first, that he was crucified but his followers were not and, secondly, that he deliberately surrendered himself to the cross. These two further facts will now be considered in turn.

Jesus died by crucifixion, that is, he was executed as a rebel by the Romans. It is a historical fact, however, that although the Romans crucified Jesus, and were capable of crucifying hundreds at a time, they did not crucify Jesus' disciples or other followers. They did not punish his followers or friends for anything they did in his lifetime. There is no evidence of any of the disciples or other followers being rounded up following Jesus' arrest; the disciples seem to have gone about unmolested by the Romans, in Jerusalem as well as in Galilee (Gal. 1.18-19; Acts 9.26-30). According to Acts 4 and 5, disciples were arrested by the Jewish authorities after Jesus' death for preaching the gospel, but they were released or escaped, and continued their preaching. Stephen was stoned to death by an angry Jewish mob (Acts 7.58) and a persecution of Jesus' other followers by the Jewish authorities ensued (Acts 8), but the Roman garrison do not seem to have taken any action against them. We have no evidence of any of them being crucified at the time. According to church tradition, Peter was crucified, but in Rome, and much later, and Paul's trial before Felix in Jerusalem on the accusation of Jews, which led to his being sent to Rome, also came much later.

Jesus being crucified but his followers being spared puzzles scholars. Justin Meggitt, for example, writes that it 'seems to go against what we can discern of both the general practice and principles of Roman rule. ${ }^{2}$ It was the Roman practice with revolutionary groups, though, to crucify their leaders, while often letting followers go free. The Romans could not crucify everyone in the empire

2 Justin J. Meggitt, 'The Madness of King Jesus: Why was Jesus Put to Death, but his Followers were not?', JSNT 29 (2007), pp. 379-413 (383). 
who rose against them, and they did not attempt to. Instead, they crucified the leaders with great cruelty and publicity as a deterrent to anyone who might be tempted to revolt, but they did not pursue the followers, at least if they had not fought against the Romans or the local authorities. Three examples follow; in several years investigating Jesus' reason for surrendering, I have not seen any of them mentioned in that connection and I believe that what follows is unique. The first example is from shortly before Jesus was born, the second from when he was a young man, and the third from shortly after his death:

1. Following the death of Herod the Great in 4 bce, there were revolts in Judaea. Publius Quinctilius Varus, the Roman Legate of Syria, put down the revolts and, according to Josephus (Ant. 17:295; J.W. 2:75-78), had 2,000 of the rebels crucified. However, when $10,000^{3}$ Jews who had joined together to rebel and had armed themselves but had not yet proceeded to fight then changed their minds and surrendered to Varus, he forgave all but the commanders for the crime of rebelling. He sent the commanders to Caesar, who condemned only those of them who were relatives of the Herods and so had armed themselves against their own kin (Ant. 17:297299;J.W. 2:75-78). ${ }^{4}$

2. In 17 Ce, Tacfarinas, an auxiliary in the Roman army in Africa, deserted and formed an army of his own, organized on Roman lines. Headed by him, the army mounted a substantial armed rebellion, lasting nearly ten years, the Ninth Legion had to be sent from Pannonia (on the Danube) to help defeat it, three Roman commanders were granted 'triumphs' in Rome for successes in the field, and one of them, Blaesus, the even rarer title of honour, 'Imperator', as well. ${ }^{5}$ At the height of the rebellion, Tacfarinas demanded a grant of land and a peace treaty. This infuriated Tiberius, who entrusted the matter to his general Blaesus, with instructions to induce the other rebels to believe that they could lay down their arms with impunity, but to seize the leader by whatever means (dat negotium Blaeso ceteros quidem ad spem proliceret arma sine noxa ponendi, ipsius autem ducis quoquo modo poteretur). (Tacitus, An 3.73). Many followers came in under the amnesty. This was an example of clemency to followers actually fighting to throw off the Roman yoke.

3 This and the previous figure may be exaggerated, as Josephus habitually exaggerates such figures.

4 See E. Mary Smallwood, The Jews under Roman Rule from Pompey to Diocletian: A study in political relations (Leiden: Brill, 1981).

5 Tacitus, An 3.74. 
3. In $36 \mathrm{Ce}$, Pilate put down an uprising in Samaria, but punished only the principal and powerful men among the many who fled. He was then accused of murdering them and was sent to Rome to answer the charge (Ant. 18:85-89).

\section{Jesus Deliberately Surrendered Himself to the Cross}

\subsection{The Synoptic Gospels}

Even looking only at the Synoptic Gospels and secular literature, ${ }^{6}$ it can be seen that Jesus deliberately surrendered himself to the cross. He knew he was in danger, especially in Judea, ${ }^{7}$ and could have hidden himself away in Galilee, but he goes instead to Jerusalem, where the danger is greatest, and at the Passover, a particularly dangerous time. Josephus wrote that it was on such festive occasions that sedition was most likely to break out. ${ }^{8}$ Accordingly, at Passover, Roman troops would come from their headquarters at the port of Caesarea to the Antonia Fortress overlooking the Temple, on the lookout for any disturbances breaking out among the vast and excited crowds of pilgrims. ${ }^{9}$ Jesus knew that John the Baptist had been killed (Mk 9.13). ${ }^{10}$ The Jewish authorities had resolved to arrest Jesus by stealth and kill him (Mk 14.1//Mt. 26.3//Lk. 22.2). Jesus may not have known about the meeting at which this was decided, but he would probably have learned what was happening when the police came to arrest him, only to leave him for fear of the crowd (Mk 12.12//Mt. 21.46//Lk . 20.19). Yet, in the Synoptic Gospels, Jesus stays in Jerusalem, teaching openly in the Temple until he is arrested (Mk 14.49//Mt. 26.55 b//Lk. 22.53). At his arrest, one of the disciples cuts off the ear of one of the arresting party (Mk 14.47//Mt. 26.51//Lk. 22.50), but according to Mt. 26.52, Jesus immediately tells

$6 \quad$ We shall come to the Fourth Gospel next.

7 Judea was under direct Roman imperial rule, whereas in Galilee the Roman sway was exercised through Herodian kings, see on the result Donald Senior, C. P., 'History and Theology in the Johannine Presentation of the Causes for the Death of Jesus: John 11: $45^{-53}$ as Convergence Point' in Paul N. Anderson, Felix Just, S. J., and Tom Thatcher eds, John, Jesus and History, III Glimpses of Jesus through the Johannine Lens (Atlanta, GA: SBL Press, 2016), pp. $43^{-} 5^{8}\left(5^{2-53)}\right.$.

8 Josephus wrote this in J. W. 1.88 in relation to much later events, but it is also true of Jesus' time.

9 See Paula Fredriksen, Jesus of Nazareth King of the Jews: A Jewish Life and the Emergence of Christianity (Basingstoke: Papermac, 2001), pp. 252-54.

$10 \quad$ Mark 9.13 refers to John the Baptist. See also an early plot to destroy Jesus at Mk 3.6. 
the disciple to sheathe his sword; according to Lk. 22.51, Jesus says 'Enough of this, ${ }^{11}$ and the disciples seem to have offered no further resistance.

The Synoptic evidence indicates that not only did Jesus go unresisting to the cross, he deliberately went to teach openly at a time and place where the danger of being arrested was at its peak, knowing that crucifixion was a likely result, and instructed those with him not to resist his arrest. He deliberately surrendered himself to the cross. ${ }^{12}$ Ancient authors, including the evangelists, saw nothing wrong with inventing speeches and putting them into the mouths of historical characters. For that reason, Gospel accounts of sayings need to be treated with considerable reserve. Gospel accounts of the movement of characters from place to place are, however, less likely to be invented. Here, the secular evidence would be enough to show that Jesus would have known the danger he was in, it is reasonable to accept the Gospel evidence that he went and taught in the Temple, the fact that he was arrested but those with him were not helps to show they did not resist, and it is easy to deduce that this must have accorded with Jesus' wishes. I would urge that this is sufficient evidence of surrender.

\subsection{The Gospel of John}

John has strong evidence that Jesus deliberately surrendered himself. He might have hidden somewhere in Galilee, for example, following many attempts to arrest him $(\mathrm{Jn} 7.32,8.37,10.39,11.57)$, but he leaves and goes to Jerusalem, where the danger is greatest. According to Jn 11.54, after the Sanhedrin has resolved to put him to death, Jesus goes with his disciples to 'Ephraim' near the wilderness, presumably for safety. It is from there that he comes to Jerusalem for his final Passover, and he hides there again for a time (Jn 12.36b). He could have continued to hide, but instead he teaches openly until he is arrested.

In the account of Jesus' arrest at Jn 18.3-9, he is with eleven of his disciples, across the Kidron valley and in a garden on the Mount of Olives, at night. A band of soldiers and others, guided by Judas, comes with lanterns and

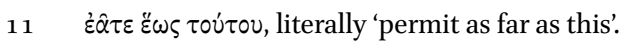

12 Jesus' cry on the cross, 'My God, why have you forsaken me?, is not inconsistent with this; he had concluded that it was God's will that he should go to the cross (Mt. 26.39//Lk. 22.42; Mk 14.36; Jn 18.11, 17) and he surrendered to it in voluntary compliance, see Jerome H. Neyrey, 'The "Noble" Shepherd in John 10: Cultural and Rhetorical Background' JBL 120 (2001), pp.267-91 (285); Andrew T. Lincoln, The Gospel According to StJohn (London: Continuum, 2005), pp. 298-99; Dale C. Allison, Constructing Jesus: Memory, Imagination and History (London: SPCK, 2010) p. 433. 
torches. Jesus must have seen them coming, ${ }^{13}$ but he does not hide or run away. Instead, he confronts them and asks who they are looking for. They answer,

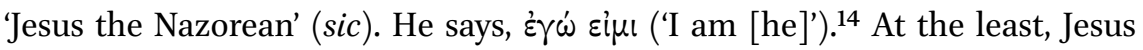
indirectly encourages his own arrest, ${ }^{15}$ but it goes further than that; he seems to have approached the search party in order to bring his arrest about. In short, as C. H. Dodd wrote, 'Jesus gave himself up to the police.'16 Allison, likewise, quotes thirty-one diverse texts and deduces from them that Jesus did not run from his death or resist it but, on the contrary, submitted to it. ${ }^{17}$ I would urge that we can adopt that conclusion.

\section{Why Did Jesus Surrender Himself?}

\subsection{The Synoptic Gospels}

At Mk 10.45//Mt. 20.28, Jesus says that the son of man (meaning himself) $)^{18}$ came to give his life as a ransom for many ( $\dot{\delta}$ viòs $\tau 0 \hat{\alpha} \alpha \nu \theta \rho \omega \dot{\pi} \pi 0 v \hat{\eta} \lambda \theta \varepsilon v$... $\delta 0 \hat{v} v \alpha \mathrm{l}$

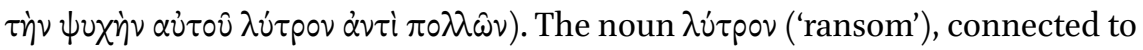
the verb $\lambda \dot{v} \omega$ ('I loose'), was often used to refer to the price for freeing a slave or prisoner of war, but it was also used in the Lxx to refer to the price of a life (see Prov. 13.8). Examples include money paid by an adulterer to the wronged husband (Prov 6.35) or by the owner of a dangerous ox to the family of a man it has killed (Exod. 21.28-31). In both of these cases, the money is paid in order to buy off a death penalty that has been incurred by the payer.

Adela Yarbro Collins agrees that our text says nothing expressly about sin, but argues from the analogy of certain confessional inscriptions that atonement for sin is 'surely implied', and that accordingly $\lambda$ útpov (ransom) in v. 45 is

13 See Ernst Haenchen, John 2: A Commentary on the Gospel of John Chapters 7-21 (Philadelphia: Fortress, 1984), pp. 164-65: 'Such a military column, speckled with lights, would have been visible from quite a distance and would have permitted those who sought to flee plenty of time...But...Jesus, in John's view, did not consider fleeing.'

14 The translations here and below are mine except where otherwise noted.

15 Rudolf Schnackenburg, The Gospel According to St. John, III, Commentary on Chapters 1321 (London: Burns and Oates, 1982), p. 225.

16 C. H. Dodd, The Interpretation of the Fourth Gospel (London: Cambridge University Press, third repr., 1953), p. 432.

17 The texts are from 'Q', Mark, M, L, John, Gos. Thom., authentic Paulines, 1 Timothy, Hebrews and 1 Peter, see Allison, Constructing Jesus, pp. 428-433. Allison does not inquire into the reliability of the individual texts. We shall return to this in footnote 45 .

18 This is the meaning of the phrase here, whether or not its use implies that Jesus was referring to Daniel 7.13. 
a synonym of i $\lambda \alpha \sigma \tau \eta^{\prime} \rho 10 v$ (propitiation). ${ }^{19}$ I would urge that, rather, if one puts out of mind the traditional post-Easter teaching that Jesus died for sinners and

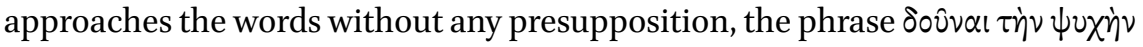
$\alpha \dot{v} \tau 0 \hat{v} \lambda \dot{v} \tau$ pov $\dot{\alpha} \nu \tau i \mathrm{i} \pi \circ \lambda \lambda \hat{\omega} \nu$ (to give his life a ransom for many), which does not mention sin, looks more like a gift of a life for lives in the same way as, in the examples of the ox and the adulterer, the (monetary) ransom saves its giver from the death penalty incurred. Yarbro Collins says on the previous page of her book that $\alpha v \tau i$ here carries the sense of 'in place of', implying that Jesus gives his life in place of many others, and that seems the correct interpretation. The word $\alpha v \tau i$ has a sense similar to that in Mt. 5.28, $\dot{\partial} \varphi \theta \alpha \lambda \mu \dot{\partial} \nu \dot{\alpha} \nu \tau i \dot{o} \varphi \theta \alpha \lambda \circ \nu$ (an eye [in return] for an eye). In Mk 20.28, though, $\pi \circ \lambda \lambda \hat{\omega} v$ is masculine, while $\psi v \times \eta \dot{\nu}$ is feminine, so the saying does not literally speak of giving a life for many lives, but of giving it for many people. Nonetheless, the meaning is that the death of Jesus is a substitute for the deaths of many others, as Yarbro Collins phrases it. ${ }^{20}$ There is no reason to take this as referring to anything other than bodily deaths such as Jesus was surrendering to. In the inscriptions quoted by Yarbro Collins, the ransom is dedicated to a god or a sacred village, whereas in our saying it is surrendered to the Roman occupying forces, which were neither divine nor sacred, and not as a propitiation but merely as the extent of the punishment that they imposed in such cases.

The saying about a ransom 'for many $(\pi \circ \lambda \lambda \omega v)$ ' might be thought inapplicable to a surrender to save only the eleven disciples who were with Jesus when he surrendered, but they were not the only people who might have been in danger if he had not surrendered. The evangelist's comment at Jn 18:9 indicates that Jesus was protecting all whom God had given to him, not only the disciples in the front rank. It is true that $\pi \circ \lambda \lambda \omega \nu$ here, even without the definite article, could translate an Aramaic expression that could itself be translated 'for the many',21 to be understood as 'all', but I would suggest that the word is flexible enough to be confined to all of Jesus' followers, rather than extending to all Jewish people, as in Qumran documents it is confined to the Qumran

\footnotetext{
19 Adela Yarbro Collins, Mark: A Commentary (Minneapolis, MN: Fortress, 2007), p. 503, and see also her 'Mark's Interpretation of the Death of Jesus', JBL 128 (2009), pp. 545-54 (549).

20 Collins, Mark, p. 502.

21 Joachim Jeremias, The Eucharistic words of Jesus (London: SCM, 1964), pp. 317-25; W. D. Davies and Craig C. Allison Jr., A Critical and Exegetical Commentary on the Gospel according to Saint Matthew. 3 vols. Edinburgh: T \& T Clark, 1988-1997, vol 3, p. 95; against Ulrich Luz, Matthew 8-20: A Commentary (Minneapolis: Fortress, 2001), p. 546, n. 42. Maurice Casey, Aramaic Sources of Mark's Gospel (Cambridge: Cambridge University Press, 1998), pp. 193-4 has a different reconstruction.
} 
community, a relatively small part of the Jewish people, ${ }^{22}$ and as the 'the slave of all' $(\pi \dot{\alpha} \nu \tau \omega \nu)$ in the immediately preceding verse 44 refers to all 'among you' ( $\dot{\varepsilon} \nu \dot{u} \mu \hat{i} \nu)$ - the disciples engaged in the discussion.

Funk says that the ransom saying in Mk 10.45 is Mark's creation, ${ }^{23}$ and Bultmann considered it impossible to discover Jesus' reason for going to his death. ${ }^{24}$ Allison, though, 'more than inclines' to assume that the phrase 'the son of man'

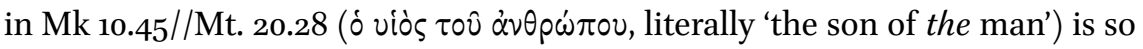
strange in Greek that an Aramaic equivalent goes back to Jesus. ${ }^{25}$ Moreover, Maurice Casey reconstructed what he judged to have been the original Aramaic of the whole of Mk $10.35-45{ }^{26}$ This being possible indicates that the verses were originally in Aramaic, leading to a similar assumption. It indicates that they came into being early and are unlikely to have been invented by the evangelists, who wrote in Greek, or their Greek-speaking communities. ${ }^{27}$

I would suggest that, on balance, the saying about the ransom goes back to the historical Jesus, but if it does not, it is still useful evidence of what Jesus' intention was considered to have been at a time comparatively soon after his death.

From the Synoptic evidence that we have just seen, it is possible to deduce the reason why Jesus surrendered himself to the cross. He must have done it for others, and it is likely that those he intended to benefit included his disciples and other friends. The clues about the nature of the intended benefit are the facts that, following the same course as Varus with the rebels who surrendered without fighting, the Romans crucified Jesus, the leader, but not his followers,

22 See Morna D. Hooker, The Gospel According to Saint Mark, reprint (London: Continuum, 2005), p. 249.

23 Robert W. Funk, Roy W. Hoover, and the Jesus Seminar, The Five Gospels: The Search for the Authentic Words of Jesus (New York: Scribner, first edition, 1996). This work is hereafter referred to as 'Funk'.

24 Rudolf Bultmann, 'The Primitive Christian Kerygma and the Historical Jesus,' in Carl E. Braaten and Roy A. Harrisville (eds.), The Historical Jesus and the Kerygmatic Christ: Essays on the New Quest of the Historical Jesus (New York: Abingdon, 1964), pp. 22-33 as quoted in Allison, Constructing Jesus, p. 428.

25 Allison, Constructing Jesus, p. 293. I am doubtful, though, about his suggestion on p. 294 that in speaking of himself as the son of man Jesus was sometimes referring to Daniel 7 .

26 Maurice Casey, Aramaic Sources of Mark's Gospel (Cambridge: Cambridge University Press, 1998), pp. 193-94.

27 Craig R. Evans has a full argument for the authenticity of the saying, and I would urge agreement with the result, though I do not agree with all of his reasoning, see his Mark 8:27-16:20, pp. 119-125. Rainer Reisner also has strong arguments for the authenticity of the saying, see 'Back to the Historical Jesus through Paul and his School (The Ransom Logion Mark 10:45; Matthew 20:28)', JSHT 1.2 (2003), pp. 171-99 (177-99). However, I cannot share what seems to be a presupposition of Reisner (172) that Jesus was speaking of atonement. 
and that Jesus and those with him did not in the end resist. From those clues, we can deduce that Jesus believed, or hoped, that if he surrendered himself to the cross without resisting, his followers would not be pursued, and accordingly he went to the cross as a ransom for his followers, to save them from suffering a similar fate.

It is true that several rebels were punished after the revolt quelled by Varus and also after that quelled by Pilate, whereas Jesus alone was crucified, but how many leaders needed to be killed depended on the circumstances. ${ }^{28} \mathrm{Ti}-$ berius called for Tacfarinas alone to be seized in quelling the revolt led by him, and his assessment proved to be correct. Tacfarinas fought on after a defeat in which his brother was captured, and Blaesus' successor Dolabella saw that unless the leader was cut down there would be no rest from the war (non nisi duce interfecto requiem belli fore). ${ }^{29}$ In the end, seeing himself losing his last battle, Tacfarinas threw himself on the enemy spears, and as Tacitus says, this ended the war (isque finis armis impositus). ${ }^{30}$ Jesus and Caiaphas each considered that the Romans would calculate that in the circumstances a single death would be enough to end the Jesus movement. The Romans proved to be wrong, but only because they had not foreseen the belief among Jesus' followers that their leader would return.

I have shown how the reason for Jesus' surrender can be deduced from the Synoptic Gospels because of the additional doubts entertained by many scholars about the reliability of the Fourth Gospel, ${ }^{31}$ but let us now turn to that Gospel.

28 Fredriksen examines the circumstances accordingly, but for the reasons explained here I do not agree with her that, if the Romans had thought Jesus posed a political threat, more than only Jesus would necessarily have died, see Paula Fredriksen, Jesus; When Christians were Jews: The First Generation (New Haven: Yale Univerity Press, 2018), pp. 58-9.

29 Tacitus, An 4.25.

$30 \quad$ Tacitus, An 4.26 .

31 See, for example, Maurice Casey, Is John's Gospel True? (London: Routledge, 1996); James G. Crossley, Jesus and the Chaos of History (Oxford: Oxford University Press, 2015), pp. 48-63. For a more favourable view of the reliability of John, see Paul A. Anderson, 'Why This Study Is Needed and Why It Is Needed Now' in John, Jesus and History, Volume 1: Critical Appraisals of Critical Views, eds. Paul N. Anderson, Felix Just, S. J. and Tom Thatcher (Atlanta: Society of Biblical Literature, 2007) pp.13-70 (43-54), criticized by Crossley, Chaos, pp. 56-63, and more recently 'The John, Jesus and History Project and a Fourth Quest for Jesus' in Jesus, Skepticism \& the Problem of History: Criteria and Context in the Study, of Christian Origins, eds. Darrell L. Bock and J. Ed. Komoszewski (Grand Rapids, Michigan: Zondervan Academic, 2019), pp. 222-268. 


\subsection{The Gospel ofJohn}

In the Fourth Gospel, the reason why Jesus surrendered is to be found in the account of his arrest (John 18:3-9). In this account, Jesus is with eleven of his disciples, across the Kidron valley and in a garden on the Mount of Olives, at night. A band of soldiers and others, guided by Judas, comes with lanterns and torches. Jesus must have seen them coming, ${ }^{32}$ but he does not hide or run away. Instead, he confronts them and asks who they are looking for. They answer,

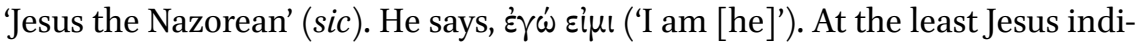
rectly encourages his own arrest, ${ }^{33}$ but it goes further than that; he approaches the search party in order to bring about his arrest. In short, he gives himself up. C. H. Dodd rightly calls Jesus' confronting the arresting party 'his noble gesture in giving himself up to secure the escape of his followers. ${ }^{34}$ Allison likewise quotes thirty-one diverse texts and deduces from them that Jesus did not run from the cross but submitted to it. ${ }^{35}$

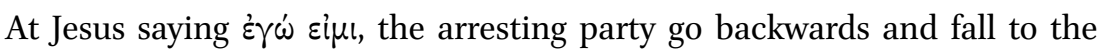
ground. The ordinary phrase resembles God's name for himself at Exod. 3:14

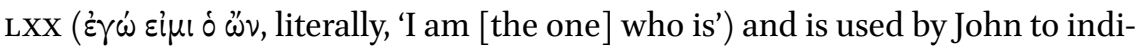
cate that Jesus was divine. ${ }^{36}$ We need not consider whether the expression truly had such a dramatic effect on the arresting party, or indeed whether Jesus intended to invoke Exod. 3:14. According to John 18:7, Jesus asks the arresting party again who they are looking for, they again say, 'Jesus the Nazorean' and he says, 'I told you that I am he; so, if you are looking for me, let these men go'

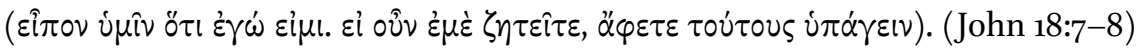
This is sometimes characterized as a demand, a command or an order, ${ }^{37}$ but it

32 See Ernst Haenchen, John 2: A Commentary on the Gospel of John Chapters 7-21 (Philadelphia: Fortress Press, 1984), pp. 164-65: 'Such a military column, speckled with lights, would have been visible from quite a distance and would have permitted those who sought to flee plenty of time...But...Jesus, in John's view, did not consider fleeing.'

Rudolf Schnackenburg, The Gospel According to St.John, II Commentary on Chapters 13-21 (London: Burns and Oates, 1982), p. 225.

34 C H Dodd, Historical Tradition in the Fourth Gospel (Cambridge: Cambridge University Press, 1963), p. 75.

35 The texts are from 'Q', Mark, M, L, John, Thomas, authentic Paulines, 1 Timothy, Hebrews and 1 Peter, see Allison, Constructing Jesus, pp. 428-33. Following his frequent practice (see Constructing Jesus $15^{-20}$ ) Allison relies on a communal memory without inquiring into the reliability of the individual texts.

36 As, for example, at John 8:24, 28, 58 ('Before Abraham was, I am'); 13:19.

37 E.g. Raymond E. Brown, The Death of the Messiah: From Gethsemane to the Grave: A Commentary on the Passion Narratives of the Four Gospels (London: Geoffrey Chapmen, 1994), vol. 1, p. 29o: 'a demand of the all-powerful Jesus'; Lincoln, St John. p. 445, 'command'; Jerome H. Neyrey, The Gospel of John (Cambridge: Cambridge University Press, 2007), 120: 'command'. 
reads more like a request, consequent on Jesus' surrender. ${ }^{38}$ As Jesus was the one the search party were looking for, presumably the one they had been sent to arrest, and he had given himself up, they could let the others go.

In surrendering himself and saying what he did about letting his companions go, Jesus was protecting them. This is confirmed, if confirmation be needed, by the evangelist's comment at Jn 18.9 that Jesus did and said what he $\operatorname{did}^{39}$ in order to fulfil an earlier statement that he had lost not one of those who had been given to him (Jn 17.12, and see 6.39). ${ }^{40} \mathrm{Jn}$ 18.3-9 suggests, even more clearly than the Synoptic evidence, that Jesus calculated, or hoped, that if he surrendered himself, his followers would not be pursued, and that accordingly he surrendered himself to death on the cross to save them from suffering the same fate.

The material in John additional to that in Mark, such as Jesus' request to let the disciples go and the names of Peter and Malchus in the incident of the ear, could have been in Mark's source but disregarded by him, or in an independent source of John's, or John could have received a more detailed version of events from Mark's source than Mark did, or he could have contributed the details out of his own imagination to add verisimilitude to the story. It is not possible to say where the additions came from or how, but the fact that Jesus was crucified while those with him were allowed to go free provides convincing background support for the account of the request.

Mark 14.50 and Mt. 26.50 also provide some support. There, as in John, the disciples flee when Jesus surrenders himself. The Synoptic Gospels do not record Jesus asking the arresting party to let them go, as in John, but they are consistent with his having done so. Mark 14.50 and Mt. 27.56 say that the disciples forsook or abandoned Jesus ( $\dot{\alpha} \varphi \dot{\varepsilon} v \tau \varepsilon \varsigma \alpha \dot{\tau} \tau \dot{\partial} v$ ), and they may well have felt that they were doing so, but I suggest that he would have wished them to save themselves.

The conclusion that Jesus died to save his followers' lives is further supported, though perhaps less securely, by two sayings of Jesus in John: 'I am the good shepherd. The good shepherd lays down his life for the sheep' (10.11 and see 10.15 b), and 'Greater love has no man than this, that a man lay down his life for his friends' (15.13). Those passages have traditionally been interpreted as referring to Jesus laying down his life to save followers and friends from their sins,

38 Schnackenburg, John 13-21, p. 225 and Brown (Death, vol. 1, p. 289) both say Jesus was bargaining for the release of his disciples, but he was in no position to bargain. companions go, but also to his identification of himself in the same sentence as the one the search party is looking for, by which he surrenders. 
but they say nothing (at least expressly) about sin and seem more appropriate to saving followers and friends from an earthly death, especially as the saying about the shepherd is followed by a reference to a wolf snatching the sheep (v. 12), and an earthly death is what Jesus' followers were immediately spared. ${ }^{41}$ If the traditional interpretation is put out of mind, an implication can be perceived in each of the sayings that Jesus gives his life for the lives of his followers and friends.

Neither of the two sayings in John is derived from the Synoptic Gospels. It is possible that each is from a separate source of John's or that he or his community invented them. Scholars dispute whether the two sayings go back to the historical Jesus. The Jesus Seminar colour Jn 10.11 black to indicate that 'Jesus did not say this'. Jan van der Watt, though, applying communal memory theory, concludes that there is some possibility that Jesus could have said something along the lines of 15.13 about laying down life for one's friends, 'although it seems unlikely that he used the exact words reported. ${ }^{42}$ Allison asserts that 'surely [Jesus] never said, "The good shepherd lays down his life for the sheep",' attributing it to the evangelist instead. ${ }^{43}$ Nonetheless, Allison includes the saying among thirty-one texts from which he finds that Jesus did not run from the cross but submitted to it, 'trusting that his unhappy fate was somehow for the good. ${ }^{44}$ I would urge that we can adopt Allison's conclusion ${ }^{45}$ and add that what Jesus did was for the good because it preserved the disciples, as the evangelist's comment at Jn 18.9 indicates, and furthermore that we can adopt the

41 This is about the historical Jesus, even though the evangelist may have intended it as a sign that the sacrifice of the Christ of faith brought eternal life, see C. H. Dodd, Historical Tradition in the Fourth Gospel, pp. 422-3.

42 Jan van der Watt, 'Some Reflections on the Historicity of the Words "Laying Down Your Life for Your Friends" in John 15:13,' in Paul N. Anderson, Felix Just, S. J. and Tom Thatcher (eds.), John, Jesus and History, III Glimpses of Jesus through the Johannine Lens (Atlanta: SBL Press, 2016), pp. 481-91 (491).

43 Allison, Constructing Jesus, p. 433.

44 Allison, Constructing Jesus, pp. 428-432.

45 Following his frequent practice, in relying on a communal memory, Allison does not inquire into the reliability of the individual texts (see Constructing Jesus, pp. 15-20). I doubt whether this is legitimate, especially where (as here) a text judged to be unhistorical is relied on; contrast John P. Meier, who only uses texts 'judged historical', see his A Marginal Jew: Rethinking the Historical Jesus, II, Mentor, Message and Miracles (New York: Doubleday, 1994) p. 14, n. 6. Allison has subsequently written a congratulatory introduction to Anthony Le Donne's Historical Jesus: What can we know and how can we know it? (Grand Rapids, MI; Cambridge, UK: Eerdmans, 2011), pp. ix-xii. However, Le Donne does not despair of establishing the authenticity of individual texts, and uses the usual criteria (embarrassment, coherence, etc.) in assessing reliability, see pp. 87-91 of his Historiographical Jesus: Memory, Typology, and the Son of David (Waco, Texas: Baylor University Press, 2009). 
more explicit conclusions of C. H. Dodd, who calls what Jesus did 'his noble gesture' in giving himself up 'to secure the escape of his followers'; ${ }^{46}$ of Thomas L. Brodie, ${ }^{47}$ that Jesus was offering himself so that his disciples might be saved; and of Helen Bond, that 'Jesus' confession in the garden defends his disciples (18.8), his "I am" saves their lives, even at the expense of his own.48 The expense here is precisely the ransom ( $\lambda \dot{\tau} \tau$ pov) for many in Mk 10.45//Mt. 20.28 considered above.

\subsection{Caiaphas's Speech}

Jesus' belief or hope that, by surrendering himself to the cross, he would save his followers from suffering a similar fate is further supported by a similar thought to be found in the speech of Caiaphas, the high priest, to the Sanhedrin: ${ }^{49}$

${ }^{47}$ So the chief priests and the Pharisees gathered the council, and said, 'What are we to do? For this man performs many signs. ${ }^{48}$ If we let him go on thus, everyone will believe in him, and the Romans will come and destroy both our holy place and our nation. ${ }^{49}$ But one of them, Caiaphas, who was high priest that year, said to them, 'You know nothing at all; ${ }^{50}$ you do not understand that it is expedient for you ${ }^{50}$ that one man should die for the people, and that the whole nation should not perish.' ${ }^{51} \mathrm{He}$ did not say this of his own accord, but being high priest that year he prophesied that Jesus should die for the nation, ${ }^{52}$ and not for the nation only, but to gather into one the children of God who are scattered abroad, so from that day on they took counsel how to put him to death. (Jn 11.48$\left.5^{2}, \mathrm{RSV}\right)$

John $18.13^{-14}$ is also relevant here; after referring to Caiaphas it continues, 'It was Caiaphas who had given counsel to the Jews that it was expedient that one man should die for the people' (RSv). This and the previous passage are the

46 C. H. Dodd, Historical Tradition in the Fourth Gospel (Cambridge: Cambridge University Press, 1963) p. 75.

47 Thomas L. Brodie, The Gospel According to John: A Literary and Theological Commentary (New York: Oxford University Press, 1993), p. 526.

48 Helen K. Bond, 'At the Court of the High Priest: History and Theology in John 18:13-24, in Paul N. Anderson, Felix Just, S. J. and Tom Thatcher (eds.), John, Jesus and History, II Aspects of Historicity in the Fourth Gospel (Atlanta: SBL Press, 2009), pp. 313-24 (320).

49 C. H. Dodd, 'The Prophecy of Caiaphas (John XI, 47-53),' in Neotestamentica et Patristica: eine Freundesgabe Herrn Prof Oscar Cullmann zu seinem 60 Geburtstag Uberreicht (Leiden: Brill, 1962), pp. 134-143 (138).

50 Some witnesses have 'for us' ( $\dot{\eta} \mu \hat{\omega} v)$ instead of 'for you' (i $\mu \hat{i} v)$; the sense is hardly affected. 
only evidence for the speech and neither was written until two or three generations later; the part about destroying the holy place looks like a 'prophecy' after the event, based on the destruction of the Temple in $70 \mathrm{Ce}$. The evangelist seems to have thought that the Pharisees had their own regular seats in the Sanhedrin, which they did not, and that the High Priesthood was a yearly office, which it was not. ${ }^{51}$ Furthermore, $\sigma \eta \mu \varepsilon i \alpha$, the word translated 'signs', is John's word for Jesus' miracles, which members of the Sanhedrin would have been unlikely to use, and $\tau \dot{\alpha} \tau \dot{\varepsilon} \kappa \nu \alpha \tau$ ¿ $\theta \varepsilon \circ \hat{v}$ (the children of God) in verse 52a was a Christian way of referring to Christians, ${ }^{52}$ which points to that verse having originated after the first Easter. Besides, the evangelist had a post-Easter theological purpose in recounting or manufacturing the speech, because it includes the prophecy in vv. $5^{-}{ }^{-2}$. John 11.50 is written, then, from a post-Easter point of view, and by someone who was ill-informed about the constitution of the Jewish rulers when Jesus was teaching and had a motive to make it up. Those factors demand caution in extracting history from the scene.

For the following reasons, though, I suggest that, even acting cautiously, we can still accept the account of Caiaphas's speech as containing the gist of something he said. First, the sentiment fits well the political situation in the Roman province of Palestine, where the native population were fractious and had demonstrated against the Romans from time to time, ${ }^{53}$ the occupying force needed to keep order and was accustomed to crucifying the leaders of revolts rather than their followers, as we have seen, and the Romans would hold the Jewish authorities responsible for any insurrections. ${ }^{54}$ Secondly, the

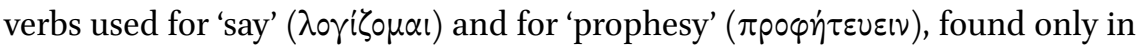
vv. 45-51 and nowhere else in John, tend to indicate that these verses are from a separate tradition that had come down to the evangelist and which he incorporated. ${ }^{55}$ Thirdly, though it is true that the phrase 'the children of God' ( $\tau \dot{\alpha}$

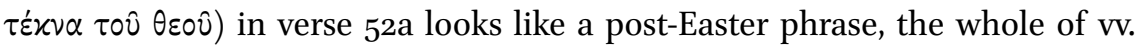
$11.5^{-} 5^{2 a}$ is a comment of the evangelist based on the traditional prophetic

$5^{1}$ On possible explanations of these "inaccuracies", see Raymond Brown, The Gospel According to John I-XII (London: Doubleday, 1966), pp. 439-40.

$5^{2}$ Often used in the Johannine Epistles, following Jn 1.10.

53 E.g. against bringing ensigns with effigies of Caesar into Jerusalem (Josephus, Ant. 18:5559; J. W. 2:169-171) and using Temple funds to build an aqueduct (Josephus, J. W. 175-177).

54 See Fredriksen, Jesus of Nazareth, p. 253. Herod the Great had deposed the high priest Matthias after protesters hacked down an eagle that the Romans had erected over one of the Temple gates, see Josephus Ant. 17:149-167.

55 See Walter Grundmann, 'The decision of the Supreme Court to put Jesus to death (John 11:47-57) in its context: Tradition and redaction in the Gospel of John,' in Ernst Bammel and C. F. D. Moule (eds.), Jesus and the Politics of His Day (Cambridge: Cambridge University Press, 1984), pp. 295-318 (305-6). 
powers of the high priest in office, ${ }^{56}$ and does not purport to have come from Caiaphas. The comment in vv. 51-52a does not, therefore, throw much doubt on the reliability of the speech itself. Fourthly, v. 53 is supported by the statements at Mk 14.1, that the chief priests and the scribes were looking for a way to arrest Jesus by stealth and kill him, and at Lk 22.2, that they were looking for a way to put him to death. (The more specific Mt 26.3-4 may also support v. 53, though its wording is so similar as to raise the suspicion that v. 53 was copied from Mt. 26.4, making it unsafe to treat it as originating from an independent source.) Finally, Jn 11.50 expresses in a purely secular way the same conception as the ransom saying at $\mathrm{Mk} 10.45,{ }^{57}$ so the two verses mutually support each other.

It seems legitimate, then, cautiously to accept Jn 11.50 as containing the gist of something said by Caiaphas. So, Caiaphas seems to have thought that if the Temple authorities surrendered Jesus to the Romans, others would not be pursued, and Jesus thought that if he surrendered himself, others would not be pursued. It was not unreasonable for Caiaphas or Jesus to form those views, because, as we have seen, it was a Roman practice to crucify the leaders of revolts without pursuing their followers.

\section{5}

Jesus' Reason Established on the Least Doubtful Evidence

Even without any of the other, confirmatory, evidence that we have considered, I contend that we can reach a reliable conclusion about what Jesus was doing by combining evidence from secular sources with evidence from the Synoptic Gospels and the comment that the evangelist undoubtedly makes at Jn 18.9. From the secular history of Roman criminal practice, we can see that Jesus was justified in believing or hoping that if he surrendered without resistance, although he would be crucified as leader, his followers would not suffer. From the secular history of the increased Roman presence and volatile crowds in Jerusalem at Passover, we can see that it was an especially dangerous time and place for Jesus to teach in the Temple. We can see from the Synoptic Gospels without need of Jn that this is what Jesus did, before surrendering himself without resistance to the arresting party. The evangelist's comment in John confirms the deduction from the Synoptic Gospels that Jesus did this to protect his followers, and this is reinforced by the solid historical fact that, while he was crucified, they were not.

$5^{6}$ See Josephus, Ant. 11:325-336 (Jaddua); 13:299 (Hyrcanus); Brown, John I-XII, p. 444.

57 Dodd, 'The Prophecy of Caiaphas', p. 138. 
The evidence so far considered points toward a conclusion that it was to save his followers from suffering a similar fate that Jesus surrendered to the cross. We have still, though, to consider the contrary evidence.

We shall see shortly that, in Jesus' lifetime, Jewish people believed that God forgave the past misdeeds of sinners who repented. This belief seems to have continued among Christians after Jesus' death, as seen in Acts 3.19, where Peter urges those who had been involved in Jesus' crucifixion to 'Repent, then, and

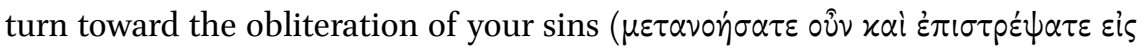
$\tau \dot{c} \dot{\varepsilon} \xi \alpha \lambda \varepsilon i \varphi \theta \hat{\eta} \nu \alpha \mathrm{l} \dot{\nu} \mu \hat{\omega} \nu \tau \dot{\alpha} \varsigma \dot{\alpha} \mu \alpha \rho \tau i \alpha \varsigma)$ without attributing their obliteration to Christ. Not much later, however, salvation began to be attributed to Christ's death. The earliest evidence is the statement of Paul at 1 Cor. 15.3 that 'Christ

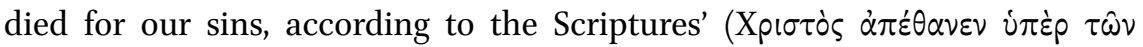
$\dot{\alpha} \mu \alpha \rho \tau \hat{\omega} \nu \dot{\eta} \mu \hat{\omega} \nu \varkappa \alpha \tau \dot{\alpha} \tau \dot{\alpha} \varsigma \gamma \rho \alpha \varphi \dot{\alpha} \varsigma)$. This certainly indicates that it was in order to save Christians from their sins that Jesus went to the cross, and it was written only about twenty years afterwards, in or about 55 ce, based on a very early creed. ${ }^{58}$ It seems, though, to be Paul's post-Easter theological construct, based on the Scriptures, rather than Jesus' own intention, based on anything he said, and is thus not very convincing evidence of Jesus' own purpose in going to the cross. It does not outweigh the conclusion to be drawn from his calls to repent that we shall shortly see. The same applies to similar statements of Paul, such as Rom. 3.24-25, 5.8, and others in Rom. 6 and Gal. 2.20, for example.

The only relevant saying that I have found of Jesus himself about dying for sinners is the saying at Mt. 26.28 that the cup at the last supper was his blood of the covenant 'which is poured out for many for the forgiveness of sins'. If reliable, the last words here would indicate that Jesus went to his death in order to obtain forgiveness for people's sins. The last words of the verse, 'for the

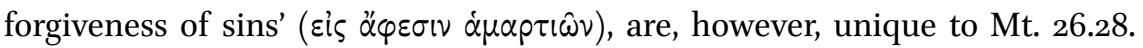
None of the parallels contains those words, including 1 Cor. 11.23-25, which means that the words are best taken as an editorial addition, as Sanders concludes. ${ }^{59}$ Inserted after the first Easter, they do not go back to the historical Jesus. Without them, the saying is consistent with the parallels, and also with

$5^{8}$ Gordon D. Fee, The First Epistle to the Corinthians (Grand Rapids, MI: Eerdmans, 1987), p. 722 .

59 E. P. Sanders, Jesus and Judaism (London: sсм, 1985), p. 112. 
Mt. 20.28//Mk 10.48, as explained above, where Jesus speaks of dying as a ransom for many, to save them from bodily death, rather than to save them from their sins. With the ransom saying properly understood in that way, there is no indication in Mark that Jesus went to the cross to save sinners from their sins. The idea that it was in order to save sinners does not seem to have arisen until some twenty years after his death, so this was not his reason.

Jesus' own belief about repentance and forgiveness also makes it difficult to believe that he went to the cross in order to save sinners, as we shall now see. Sinners

While Jesus was still alive and teaching, it was the widespread belief of Jewish people that God forgave sinners who repented. If sinners genuinely turned back from their ways and towards God, their past misdeeds would be forgiven. Sanders and Casey each say independently that the belief was universal. ${ }^{60}$ It was firmly based on the Hebrew Scriptures, ${ }^{61}$ confirmed by later writings. ${ }^{62}$ Jesus shared the belief, which means that it would not have occurred to him to surrender to the cross to save sinners; it was not needed. Instead, he urged them to repent. He would not have done this unless he believed that, when they repented, God would forgive them. The evidence for Jesus' calls to repent includes Mk 1.14-15 and Mt. 4.17, where Jesus begins his ministry by calling on people to repent ahead of the coming of the kingdom of God. At the time, Jewish people expected God to come shortly to reign as king in a new and special way from Mount Zion, bringing peace, plenty, and other blessings. ${ }^{63}$ This new kingdom of God would be accompanied by a general judgment to determine

60 E. P. Sanders, Paul and Palestinian Judaism; A Comparison of Patterns of Religion (London: scm Press, 1977), p. 75: 'The universal view of Jewish people was that every individual Israelite who indicates his intention to remain in the covenant by repenting, observing the Day of Atonement and the like, will be forgiven for all his transgressions' (Sanders's emphasis). See also Sanders, Jesus and Judaism, p. 202; Maurice Casey, Jesus of Nazareth: An Independent Historian's Account of his Life and Teaching (London: T \& T Clark, 2010), p. 292: 'It was universally accepted in Judaism that God forgave repentant sinners.'

61 Including Deut. 30:1-5; the Deuteronomistic History in Joshua to 2 Kings; Isa. 55.7; Jer. 18.7-10; Ezek. 18.17-24; Joel 2.12-14; Mal. 3.7.

62 Including the Prayer of Manasseh; 1 Enoch 50:2; Jubilees 5.17-18 and Philo (Spec. Leg. 1.187 See, too, John the Baptist's 'baptism of repentance for the remission of sins,' at Mk 1.4 and Mt. 3.6.

63 See the full account of Meier, A Marginal Jew, Vol II, pp. 237-397. 
who would be able to enter. ${ }^{64}$ Jesus' call shows that he believed God would forgive sinners who repented, allowing them to enter. The verses run:

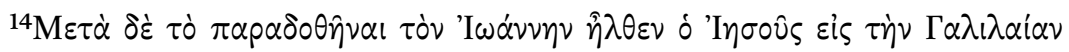

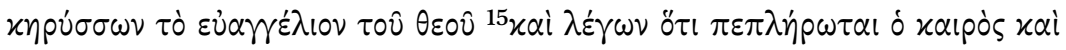

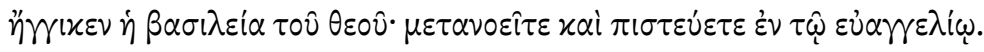

${ }^{14}$ Now after John was arrested, Jesus came into Galilee, proclaiming the good news about ${ }^{65} \mathrm{God},{ }^{15}$ and saying, "The time is fulfilled, and the kingdom of God has come near; repent, and believe in the good news.' (Mk $1.14-15)$

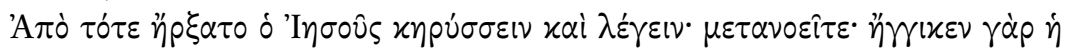

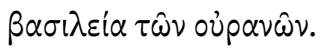

From that time Jesus began to preach, saying, 'Repent, because the kingdom of heaven has come near.' (Mt. 4.17)

Many distinguished scholars doubt whether Jesus spoke such words as are quoted in Mk $1.14-15,{ }^{66}$ but that is mainly because they misinterpret $\tau \dot{o}$

64 Jesus refers to this coming judgment (sometimes very obliquely) in fifty-nine places: in Mark: 3.28-29; 4.24; 4.25; 6.11*; 8.38 ; 9.42*; 9.43-48*; 9.49; 10.23-25*; 10.31; 12.1-12; 12.40; 13.13; and 13.20; in Matthew and Luke, but not in Mark: Mt. 5.3//Lk. 6.20; Mt. 5.25-26//Lk. 12.58-59; Mt. 7.1-2//Lk. 6.37-41 ; Mt. 7.13-14//Lk. 13.23-24; Mt. 7.22-23//Lk. 6.46; Mt. 7.2427//Lk. 6.47-49; Mt. 8.11-12//Lk. 13.28; Mt. 10.14-15//Lk. 10.11-12*; Mt. 10.28//Lk. 12.4-5; Mt. 11.6//Lk. 7.23; Mt. 11.21-24//Lk. 10.13-15; Mt. 12.27//Lk. 11.19; Mt. 12.41-42//Lk. 11.31-32; Mt. 19.28//Lk. 22.28-30; Mt. 22.2-14//Lk. 14.16-24; Mt. 23.31-36//Lk. 11.46; Mt. 23.37-39//Lk. 13.34-35; Mt. 24:39-42//Lk. 17.34-35; Mt. 24.45-51//Lk. 12.42-46; Mt. 25.11-12//Lk. 13.25; and Mt. 25.14-30//Lk. 19.20-27; in Matthew alone: 5.4; 5.7; 5.10; 5.22; 7.19; 12.36-37; 13.24-30; $13.36-43 ; 13.47-50 ; 15.13 ; 18.14 ; 18.23-35 ; 19.14 ; 21.31 ; 21.43$; and 25.21-30; 25:31-46; and in Luke alone: $6.21 \mathrm{~b} ; 6.24-26 ; 10.20 ; 12.49 ; 13.2-5 ; 13.6-9 ; 14.11 ; 16.1-31$. Of these sayings, the gist of each of the half-dozen warnings asterisked above, in particular, can be assessed as more likely than not to go back to the historical Jesus. Any one of them would be enough to show he shared the general expectation of a coming judgment.

65 Or possibly from God, see Morna D. Hooker, The Gospel According to Saint Mark (London: Continuum, 1991), pp. 53-54.

66 The scholars include Rudolph Bultmann, The History of the Synoptic Tradition, trans. John Marsh (Oxford: Blackwell, 1968), p. 118; Joachim Jeremias, New Testament Theology 1: The Proclamation of Jesus (London: SCM, 1971), p. 42; Jacques Schlosser, Le Règne de Dieu dans les dits de Jésus (Paris: Gabalda, 1980), vol. 1, pp. 96, 105; Sanders, Jesus and Judaism, p. 109 with n. 58 in reliance on Bultmann's History, p. 341 (convincingly criticized by N. T. Wright, Christian Origins and the Question of God, II, Jesus and the Victory of God (London: SPCK, 1996), p. 250 and by Dale C. Allison, 'Jesus and the Covenant: A Response to E. P. Sanders', JSNT 29 (1987], pp. 57-78 [70-74]); Meier, A Marginal Jew, pp. 430, 484, 562-63; Tessa Morgan, Roman Faith and Christian Faith: Pistis and Fides in the Early Roman Empire and Early Churches (Oxford: Oxford University Press, 2015), p. 353. See also ERV, ESv, NAB, NAU, and RSv ('the gospel'). 


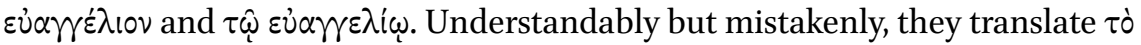
$\varepsilon \dot{a} \gamma^{\prime} \varepsilon \lambda_{10 \mathrm{~V}}$ as 'the gospel' (in the sense of the kerygma) and deduce that Mk 1.14-15 came from Christian missionary preaching, so does not go back to the historical Jesus. But $\varepsilon \dot{\jmath} \alpha \gamma \varepsilon \dot{\lambda} \lambda$ เov does not always mean gospel; it means 'good news', and what the news is about has to be gathered from the context. Different contexts can require different meanings, rebutting the presumption that a word's meaning in one part of a document is the same as its meaning in an-

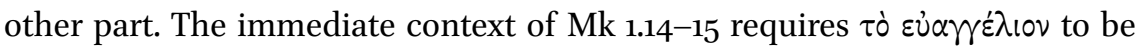
understood as the good news about the kingdom. ${ }^{67}$ Mark 1.14 does not speak of

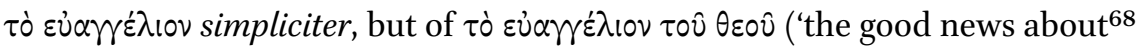
God'). This comes just before the announcement at 1.15 that the kingdom of God had come near and following on from that comes the injunction to believe in the good news, $\dot{\varepsilon} \nu \tau \hat{\omega} \varepsilon \dot{v} \alpha \gamma \varepsilon \lambda i i_{\varphi}$. The approach of the kingdom, expected to bring long life, peace, and plenty, was indeed good news. Understood by reference to the immediate context as required by ordinary principles of grammatical interpretation, the good news here is the news of the coming of the kingdom of God. ${ }^{69}$

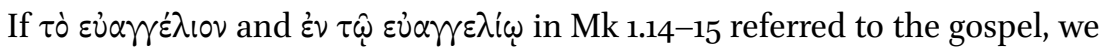
would be forced to agree that Jesus did not say anything like those verses. The gospel was a formulation of the churches that could not have been framed before the first Easter. Jesus' hearers had never heard of the gospel, so Jesus would not have spoken to them about the good news in the sense of the gospel. What he would have done was proclaim good news in Aramaic (see the next paragraph), referring to the news- good for those who had repented — of the coming of the kingdom. The scribes of some Koine and Western texts understood that Jesus was referring to the coming of the kingdom when they changed

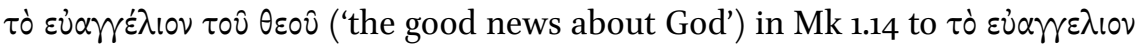

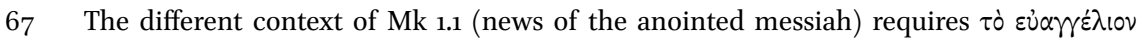

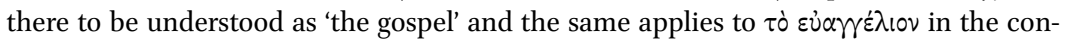
texts, different again, of Mk 8.35, 10.29, 13.10, and 16.15, and similarly in the contexts of Rom. 1.1, 15.16; 2 Cor. 11.7; 1 Thess. 2.2, 8; and 1 Pet. 4.17.

68 Again, possibly from God.

69 This is the view of C. E. B Cranfield, The Gospel According to Saint Mark (Cambridge: Cambridge University Press, 1959), pp. 62-68; Vincent Taylor, The Gospel according to Saint Mark: The Greek Text with Introduction, Notes and Indexes (London: Macmillan; New York: St Martin's Press, second ed., 1966), p. 167; Robert E. Guelich, Mark 1-8:26 (Nashville: Nelson, 1989), pp. 43, 45; Charles W. Hedrick, 'Parable and Kingdom: A Survey of the Evidence in Mark', Perspectives in Religious Studies 27 (2000), pp. 179-99 (180); Joel Marcus, Mark 1-8: A New Translation with Introduction and Commentary (New York: Doubleday, 2000), p. 172; John R. Donahue and Daniel J. Harrington, The Gospel of Mark (Collegeville, MN: Liturgical Press, 2002), p. 71: 'The imminence of God's kingdom is the substance of Jesus' proclamation'. See also MIT, NIB, NIV and NRSV, 'the good news', viz of the kingdom. 
$\tau \eta \hat{\varsigma} \beta \alpha \sigma \iota \lambda \varepsilon \dot{\varepsilon} \alpha \varsigma$ ('the good news about the kingdom'). ${ }^{70}$ The general statements at

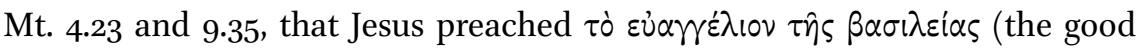

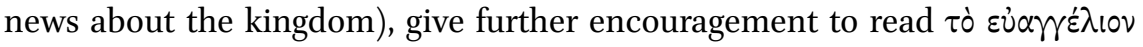
$\tau \circ \hat{v} \theta \varepsilon \circ \hat{v}$ in Mk 1.14-15 as meaning the good news of the approach of the kingdom. Traditional scholars who hold that $\tau \dot{0}$ evar the gospel, and consequently deduce that Jesus did not say it, are holding the wrong end of the stick and do not fully appreciate the importance of the kingdom in Jesus' thought. The correct deduction is that, since Jesus cannot have been referring to the gospel, he must have been referring to something elsethe good news about the approach of the kingdom as required by the context.

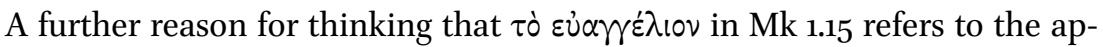
proach of the kingdom is its resemblance to Second Isaiah, especially Isa. $5 \cdot 7:^{71}$

How beautiful upon the mountains are the feet of him who brings good tidings, who publishes peace, who brings good tidings of good, who publishes salvation, who says to Zion, 'Your God reigns.'

The last verb there is מלך, 'reigns as king'. This passage, speaking of good news about God reigning as king, is highly appropriate to a saying about the coming kingdom. Jesus would have been speaking in Aramaic, however, so let us look at the targum version, which puts the Hebrew into Aramaic. The agreement between that and Mark's Greek wording is what Craig A. Evans correctly calls 'striking. ${ }^{72}$ The targum has

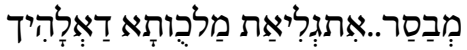

('proclaiming good news ... The kingdom of your God is revealed'), compared

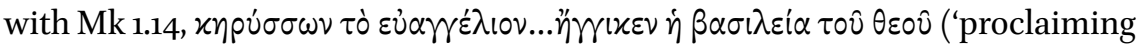
the good news...The kingdom of God has come near'). The similarity shows that Jesus was not using Christian terminology, but rather reflecting Second Isaiah, which brings the saying into line with Judaism and answers the suspicion that it comes from the Christian mission field.

70 A, D, W, the Majority text, and others, see Bruce M. Metzger, A Textual Commentary on the Greek New Testament (Stuttgart: United Bible Societies, 1971), p. 74.

71 See Guelich, Mark 1-8:26, p. 45; Craig A. Evans, 'From Gospel to Gospel: The Function of Isaiah in the New Testament,' in Craig C. Broyles and Craig A. Evans (eds.), Writing and Reading the Scroll of Isaiah: Studies of an Interpretive Tradition, II (Leiden: Brill, 1997), p. 672; Allison, Constructing Jesus, p. 113, n. 365 .

72 Evans, From Gospel to Gospel, p. 672. 


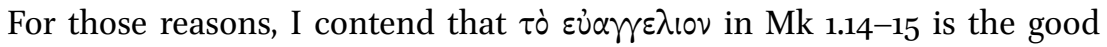
news of the coming of the kingdom, which Jesus expected, and Mark 1.14-15 is not unreliable as being anachronistic. Moreover, it accords with Jewish people's expectation of the coming kingdom and the accompanying judgment, and their belief that God forgives reformed sinners. It also shows that Jesus shared these beliefs.

Mark 6.12 confirms that something like 'Repent, because the kingdom of heaven has come near' was a refrain of Jesus' teaching. At Mk 6.7-11, Jesus sends out the Twelve and gives them instructions. Then, immediately afterwards, comes Mk 6.12: 'And they went out preaching that people should repent.' Jesus might have told the disciples what to say, but given that there is nothing in the previous verses about that, it seems more likely that the disciples knew what line to take from listening to Jesus' own teaching about the urgency of repentance. Either way, these verses of Mark tend to confirm, as a general impression, that Jesus' usual teaching included calls to repent in view of the imminence of the kingdom.

At Mk 6.6, as in previous accounts, Mark has Jesus himself going among the villages teaching. It seems likely that at 6.6 in particular, Jesus was preaching repentance, like the disciples following his instruction or example six verses later, and that he was preaching it village by village as he went.

Many scholars hold that Jesus preached repentance. ${ }^{73}$ For the foregoing reasons, I contend that we can agree with that conclusion. Jesus would not have urged repentance unless he thought that God would meet it with forgiveness. We can deduce that this is what he believed. Since Jesus believed that God forgave sinners when they repented, it would never have occurred to him to go to the cross to save sinners from their sins. What he did for sinners was to urge them to repent, as in Mk 1.15, and as he went around the villages of Galilee. This inference from Jesus' calls to repent outweighs any evidence from 1 Cor. 15.3, Mt. 26.28, and other post-Easter texts indicating that Jesus' purpose was to save

73 For example, Herbert Braun, Jesus of Nazareth: The Man and his Time (Philadelphia: Fortress, 1979), p. 40; (Mt. 1.15 correctly caught the meaning of Jesus' message); Taylor, The Gospel According to Saint Mark, p. 165 (a summary of Jesus' message); Guelich (Mark 1$8: 26$, p. 44) detects a pre-Markan tradition, and the content 'certainly corresponds to Jesus' own ministry'; Davies Allison, Matthew, vol 1, p. 389, adopt Taylor's view of Mk 1.15, and take a similar view of Mt. 4.17, saying that 'as a matter of historical fact both John [the Baptist] and Jesus did demand repentance of their hearers' (388); Allison, Constructing Jesus, p. 215: 'When Mark 1:15 summarizes Jesus' proclamation with words that include "repent", surely this catches the spirit of his message.' In Jesus of Nazareth (pp. 196-197), Fredriksen relies on Mk 1.15 (interpreted as referring to the coming kingdom) in a historical reconstruction, as does Maurice Casey in his Jesus of Nazareth, p. 219. 
sinners from their sins. It leaves standing my proposition that his purpose was to preserve his followers.

\section{Subsequent Events}

As a historical fact, by surrendering himself to the cross Jesus succeeded in preserving his followers. This enabled them to become the beginnings of the church. ${ }^{74}$ Having previously sent the disciples out to call people to repent so as to obtain forgiveness of their sins, Jesus would have expected the disciples to continue to do this after his death, and they and their successors in the church have in fact been bringing people to repentance for the forgiveness of their sins ever since. So in the end, though the forgiveness of sins was not Jesus' immediate object, it comes to Christians, indirectly but by simple historical cause and effect, through his surrender to the cross.

\section{9}

\section{Summary and Next Steps}

Jesus shared the widespread belief of his Jewish contemporaries that if sinners repented, that is turned from their ways, God forgave their past misdeeds. This did not depend on the cross, but on the merciful nature of God, who does not desire the death of sinners, but rather that they turn from their ways and live. Since Jesus shared this belief, it would not have occurred to him to go to the cross to save people from their sins. What he did for sinners was urge them to repent. Jesus' reason for surrendering to the cross was to save his followers from suffering a similar fate. This succeeded, and they were preserved to become the beginnings of the church.

Further study is now needed to explore the important consequences of our findings for the way in which the forgiveness of sins is linked to the cross. Since Jesus shared the belief that God forgives the past misdeeds of sinners who turn from their ways, of course without the cross, reformed sinners today, gentile as well as Jewish, can seek God's forgiveness in direct prayer to God without any need to rely on the cross. Nonetheless, this forgiveness comes to Christian sinners through Jesus' surrender to the cross, because his surrender preserved his followers to become the beginnings of the church and it is their successors in the church who bring Christian sinners to repentance and to the merciful God whom Jesus worshipped and who forgives reformed sinners. This traces the 
forgiveness of Christian sinners back through the cross by simple, concrete historical cause and effect - a better way than any of the many abstract, metaphorical 'soteriological theories', none of which have been generally accepted as both convincing and complete. 